\title{
Ecological ordination of the grass vegetation in Altai Krai
}

\author{
N.V. Ovcharova*, A.V. Matsyura \\ Altai State University, pr. Lenina 61, Barnaul, 656049, Russia \\ *Corresponding author E-mail: ovcharova nw@mail.ru
}

\section{Received: 10.09.2020. Accepted: 27.10.2020}

\begin{abstract}
The article shows a variety of ordination methods used to analyze different types of vegetation and presents the results of the ordinal analysis of meadow (i.a. idle lands) and steppe phytocenoses that are widespread in Altai Krai. Ecological ordination is performed by means of the Detrended Correspondence Analysis (DCA) method. The ordination of grass communities is based on 616 complete geobotanical descriptions (330 - meadow, 286 - steppe). The article determines the position of community types on the gradients of humidification and soil richness-salinity for steppes and suggests the directions of the progressive successions of idle land communities in Altai Krai.
\end{abstract}

Keywords: Phytocenoses; Ordination; Meadows; Steppes; Altai Krai

\section{Introduction}

Currently, in connection with the extensive use of computer technology, ordination methods got widespread in geobotanical research. Ordination is a collective term for multidimensional methods of processing data on the relationship of vegetation and environmental conditions. It allows arranging descriptions of vegetation along some axes, based on the data on their species composition, which makes it possible to trace the existing relationship between environmental factors and the composition of vegetation. Moreover, using methods of ordination, one can present the results of the vegetation classification and evaluate relative positions of the selected groups in regard to environmental factors. The term "ordination" was first introduced by D. Goodall (1954) and originates from the German "Ordnung", which was used by L. Ramensky (1930) to describe this approach in his publications in German. There exist two groups of ordination methods: direct and indirect.

Direct ordination displays a change in species composition along some environmental factor chosen by the researcher (humidity, altitude, etc.). Indirect ordination, however, shows a change in the species composition along some abstract axis, which reflects the maximum variability in the data structure. The advantages of direct ordination include the ease of its construction and interpretation of axes. However, since the choice of axes is carried out manually, there is always a chance to miss some factor that plays a dominant role, and there is no way to check how comprehensively the selected axes reflect the structure of vegetation. On the other hand, indirect ordination allows finding the axes that affect the variability of the species composition to the greatest possible extent. Yet, their interpretation is required in the future, i.e. finding real environmental factors that are as close as possible to the constructed hypothetical axes, which, unfortunately, is not always possible (Novakovskiy, 2008).

Table 1. Multidimensional methods of statistical analysis (Shitikov, Zinchenko, 2019).

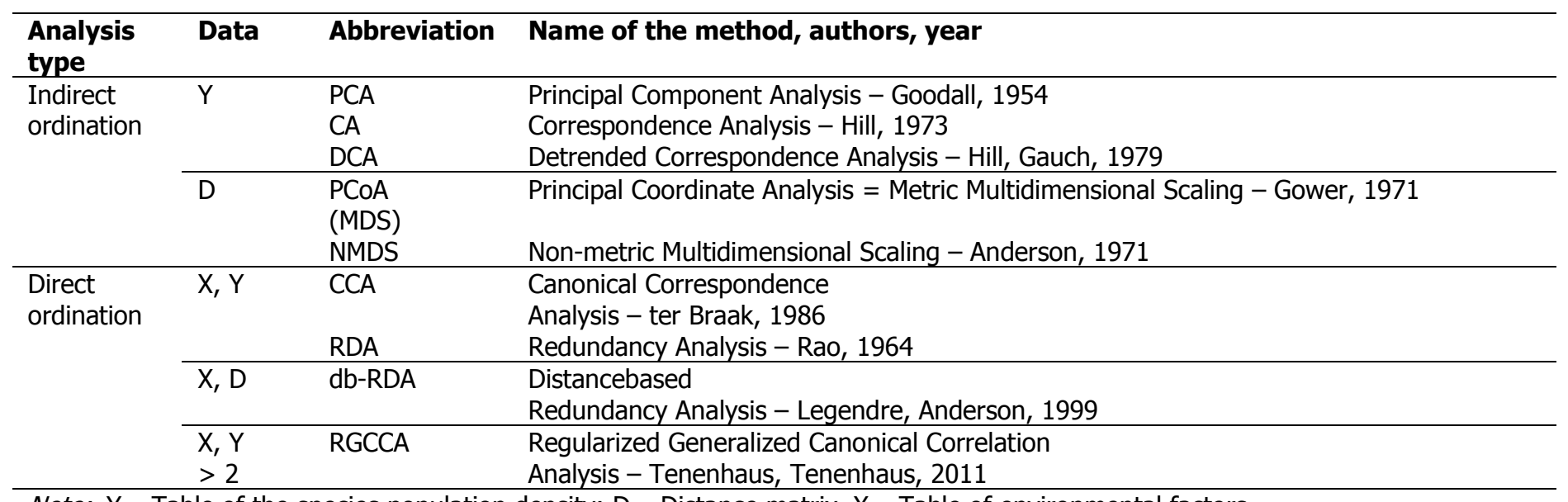

Note: $\mathrm{Y}$ - Table of the species population density; D - Distance matrix, $\mathrm{X}$ - Table of environmental factors.

Table 1 presents the distribution of the main methods of direct and indirect ordination. A greater variety of ordination methods is presented on the website of Oklahoma State University (Ordination ..., 2020).

A modern approach to studying the community ecology involves integration and joint processing of extensive observation datasets. The purpose of the performed statistical analysis is to identify significant relationships of the taxonomic structure with the characteristics of biotopes and environmental factors. It is usually based on multidimensional methods that allow for optimal projection of data with a large number of variables in small dimension spaces. 
In the general case, ordination is performed using one or several tables with the same number of rows representing the objects where observations were made (habitats, biotopes, etc.). The main table is the one that describes the ecological community under study and in its columns, contains the projective cover values of a particular plant species encountered in each habitat (matrix $Y$ ). For each pair of rows of the observation matrix $Y$, distances in the multidimensional species space that compose the distance matrix $\mathrm{D}$ can be calculated. For each habitat, the values of parallely measured external abiotic factors can be determined (matrix $X$ ). The main difference between individual multidimensional methods lies in the fact how many and which input matrices are used in the analysis. Indirect or "unconstrained" ordination is performed using only one "species-habitat" matrix $Y$ and is aimed at displaying the structural patterns of the studied community in the orthogonal coordinate system in the form of graphic projections of the populations distribution in biotopes. Ordination usually results in a combined diagram of species and / or habitats in the coordinates of two main axes. The diagram usually makes it easy to distinguish clusters of these objects, to evaluate well-interpreted patterns of relationships between the selected groups or to compare ordination plots for different time periods (Shitikov, Zinchenko, 2019).

The purpose of our work was to conduct the ordination analysis of grass vegetation in Altai Krai using the indirect DCA ordination technique in CANOCO 4.5 and DECORANA software packages with a detailed description of the step-by-step analysis.

\section{Materials and Methods}

The material for this work included 616 complete geobotanical descriptions (330 - meadow, 286 - steppe), done by the author and the staff of the Botany Department (Figure 1). The syntaxonomic analysis was performed on the basis of the Braun-Blanquet ecological floristic method (Westhoff, Maarel van der, 1973). Geobotanical descriptions were made according to the standard technique (Field Geobotany, 1964; Westhoff, Maarel, 1973) on $100 \mathrm{~m}^{2}$ sites.

In order to confirm the ecological and floristic integrity of the selected vegetation units and to identify the distribution of communities along the main axes of ordination, we used the principal component method of DCA-ordination (Detrended correspondent analysis) (Hill, 1979), implemented in the DECORANA software package. This approach is based on the principle of "mutual averaging", which allows for simultaneous ordination of communities and species.

While performing the classification and ordination, we took into account not only the species composition of communities, but also such characteristics of species as projective cover and constancy. Projective cover was assessed on a one to five scale: (+) - less than $1 \% ; 1$ - less than 5\%; $2-6-15 \% ; 3-16-25 \% ; 4-26-50 \% ; 5-$ more than $50 \%$. Geobotanical descriptions were summarized in phytocenological tables and a constancy class was established for each species: I - less than $20 \%$; II - 21-40\%; III - 41-60\%; IV $-61-80 \% ; \mathrm{V}-81-100 \%$. The nomenclature of syntaxonomic units is given in accordance with the Code of Phytosociological Nomenclature (Weber et al., 2000), taxonomic names of vascular plants are given according to S.K. Cherepanov (1995).

For ecological analysis of the grass vegetation succession patterns, we used indirect ordination by the method of Detrended correspondence analysis (DCA - ordination), implemented in the CANOCO 4.5 application software package (ter Braak, Smilauer, 2002).
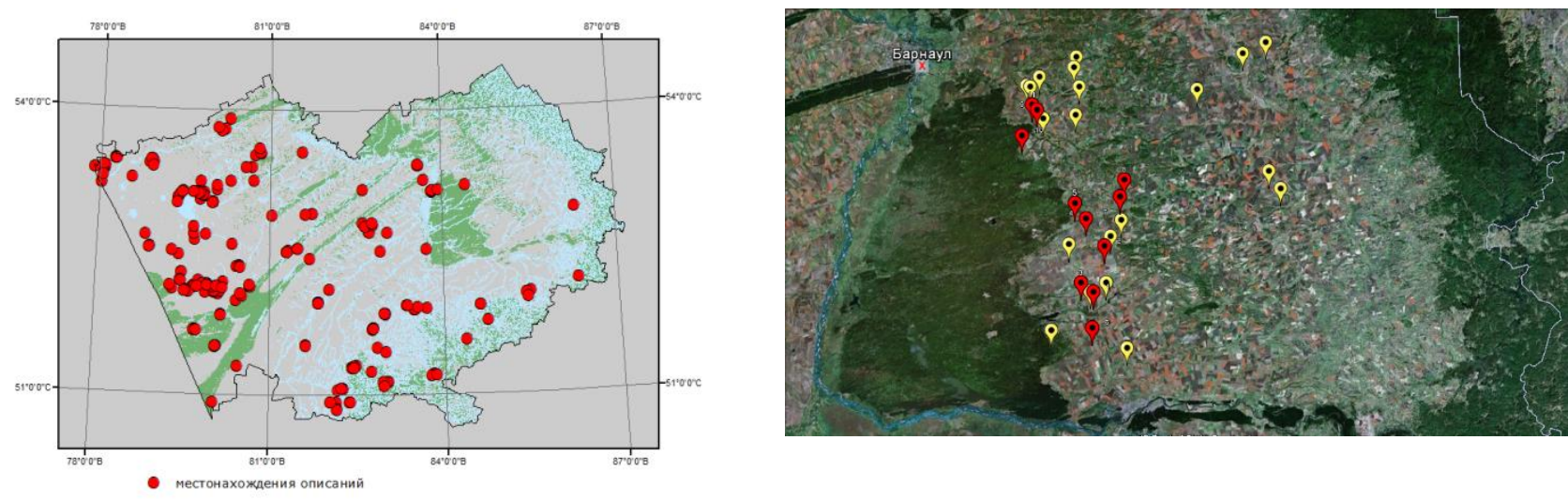

Figure 1. Distribution of geobotanical descriptions on the map-scheme of the Altai Krai territory, $a$ - steppe communities, $b$ - idle land communities.

The ordination analysis was carried out in two stages. The first stage involved qualitative ordination of grassy vegetation using the DCA ordination method presented in the DECORANA and CANOCO packages. At the second stage of the study, quantitative delimination of the obtained syntaxonomic units performed in the statistical package SPSS was carried out.

\section{Results}

Indirect ordination of grassy vegetation in Altai Krai visually shows the variability of the data and the structures existing in them. Therefore, the axes of ordination do not always have a clear biological meaning, and the task of the researcher is to find those environmental factors that are most correlated with the constructed axes. If in case of direct ordination all calculations are based on environmental factors measured directly or otherwise determined, then indirect ordination methods mainly rely on the species composition of the geobotanical descriptions under consideration. Geobotanical descriptions are considered as points in a multidimensional space where the species encountered are the coordinates of these points, or vice versa, species are points while geobotanical descriptions are coordinates. The task of ordination is to display this multidimensional picture on a plane (or in space) in such a way as to graphically show the relative position of the objects under study. One of the key conditions for such projection is the preservation of the distances between objects (their minimum possible distortion) (Novakovsky, 2008). But, despite mathematical persuasiveness and the importance of ordination approaches application, very often these methods do not give unambiguous answers and it is not always possible to interpret the distinguished axes of ordination. When the geobotanical descriptions sample is fairly homogeneous, complex gradients are difficult to determine. 
Ecological communities respond to many factors, but not all of these factors are necessarily of any interest to the ecologist. The software products CANOCO and DECORANA used in operation have the ability to "take into account" such influences. The result is partial inscription that is directly analogous to partial correlation. The variables that need eliminating are called covariates or nuisance variables.

Canoco is a multidimensional data analysis software package that focuses on two-dimensional contraction (ordination), regression analysis, and a combination of two limited ordinations. Canoco makes effective and powerful ordination methods readily accessible to scientists who want to derive and visualize the structure and the structure in complex multidimensional data , for example, to biologists who study the relationships between plant and animal communities and their environment. Canoco contains linear and unimodal ordination methods, with the possibility to consider the background change specified by covariates. In combination with extensive possibilities for reversibility tests, these methods have proved to be surprisingly effective at solving applied research problems (Ter Braak, C. J. F., 2012).

To "construct" succession series of idle land phytocenoses in Altai Krai, we carried out an indirect ordination analysis (DCA method) of syntaxons (Ovcharova, Yamalov, 2013), performed in the CANOCO program. Figure 2 illustrates the results. The first axis of the DCA - ordination includes $34 \%$ of variation, the second one $-15 \%$. The first axis is interpreted as a community age factor (succession stage), the second one is the factor of humidification. The results of syntaxonomic and ordination analysis allow constructing three hypothetical series of progressive succession according to the main factors - the community age (succession stage) and the humidification character of the habitat (Figure 2).

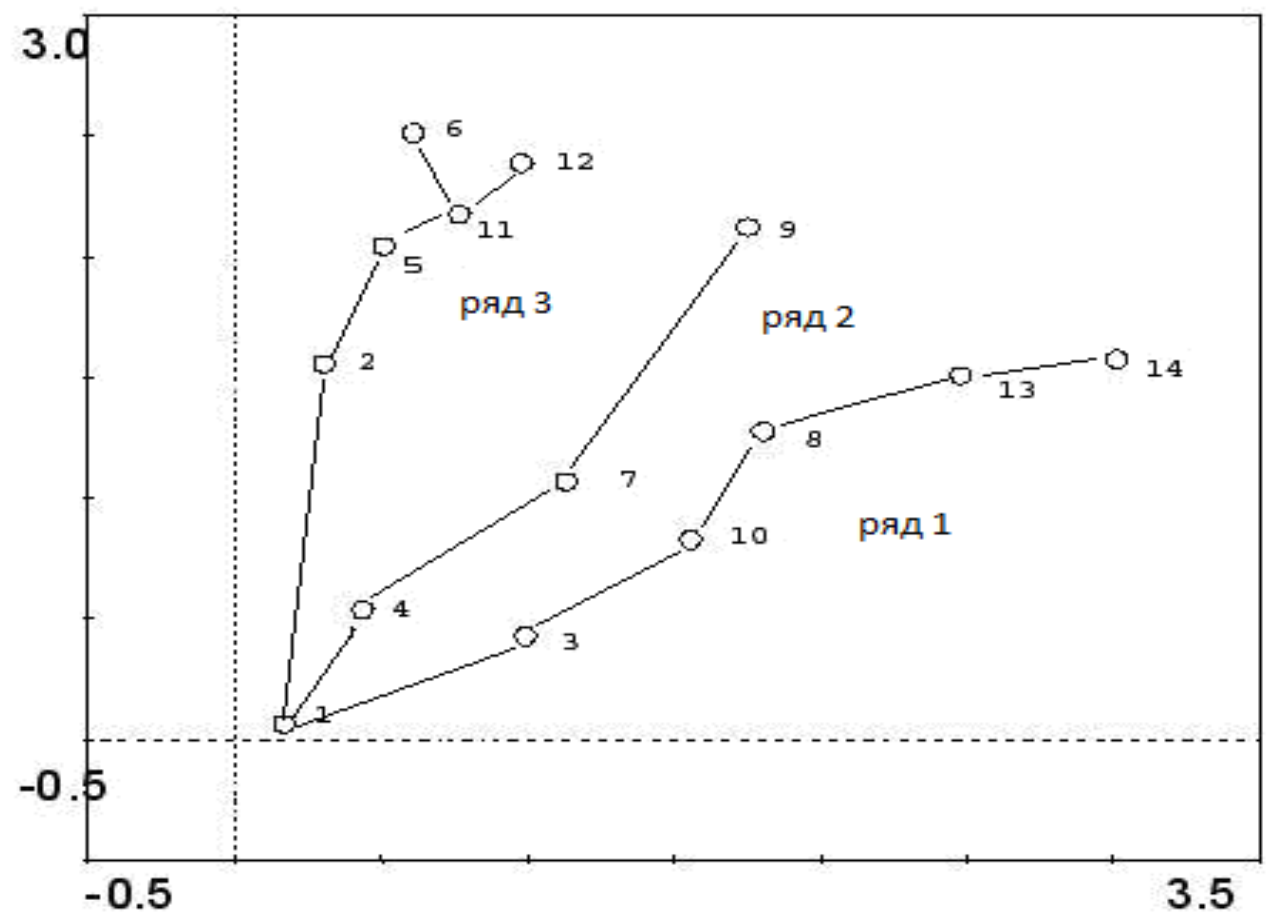

Figure 2. Position of the identified syntaxons in the space of the DCA - ordination main axes. The numbers correspond to the ordinal numbers of the syntaxons in the prodromus. Lines show the estimated directions of progressive successions in 3 series.

Series 1 - "xerophytic" - represents the community changes towards the formation of meadow steppes. Series 2 - "mesophytic" represents the community changes towards the formation of mesophytic well-hydrated meadows. Series 3 is a "hygromesophytic" series of the communities in sufficiently hydrated habitats towards the formation of mesophytic and moderately wet meadows.

The constructed succession series make it possible to reveal the dynamics of the main aggregator - species saturation of the communities (number of species per $100 \mathrm{~m}^{2}$ ).

Synoptic descriptions of the selected communities were ordinated. The age of the idle lands was distriduted into 4 classes: age class I - less than 5 years; class II - 5-7 years; class III - 10-14 years, class IV - 15-20 years.

While analysing successions, the method of constructing phytosociological spectra of communities of different syntaxons identified in syntaxonomic analysis was also used. In other terms, the proportion of groups of species associated with different higher units of ecological and floristic classification in the composition of the cenoflora core (species above constancy class II) (Mirkin, Naumova, 2012) was determined. The prodromus of the idle land communities is presented below.

\section{Prodromus of idle land communities}

STELLARIETEA MEDIAE R. Tx. et al. ex von Rochow 1951 class

SISYMBRIETALIA J. Tx. ex Görs 1966 order

Atriplicion Passarge 1978 alliance

Conyzo canadensis-Lactucetum serriolae Lohmeyer in Oberdorfer 1957 (1) association

ARTEMISIETEA VULGARIS Lohmeyer et al. ex von Rochow 1951 class

AGROPYRETALIA REPENTIS Oberdorfer et al. ex Th. Müller et Görs 1969 order

Poa pratensis [Agropyretalia repentis] (2) basal community

Agrostis tenuis [Agropyretalia repentis] (3) basal community

Convolvulo arvensis-Agropyrion repentis Görs 1966 alliance

Convolvulo arvensis-Brometum inermis Felföldy 1943 (4) association 
MOLINIO-ARRHENATHERETEA R. Tx. 1937 class

MOLINIETALIA Koch 1926 order

Potentillion anserinae R. Tx. 1947 alliance

Agrostis stolonifera (6) community

ARRHENATHERETALIA R. Tx. 1931 order

Festucion pratensis Sipajlova et al. 1985 alliance

Festuco pratensis-Dactyletum glomeratae Dymina in Maltseva et Macunina 2008 (12) association

Bromopsis inermis (5) community

Poa pratensis (7) community

Agrostis clavata (11) community

Agrostis tenuis (9) community

GALIETALIA VERI Mirk. et Naumova 1986 order

Союз Trifolion montani Naumova 1986 alliance

Poa angustifolia (8) community

Elytrigia repens (10) community

Nonea pulla-Poa angustifolia (13) community

Vicia amoena-Poa angustifolia (14) community

Based on indirect ordination (DCA method), we conducted the analysis of the higher units of steppe vegetation in Altai Krai (Figure 3).

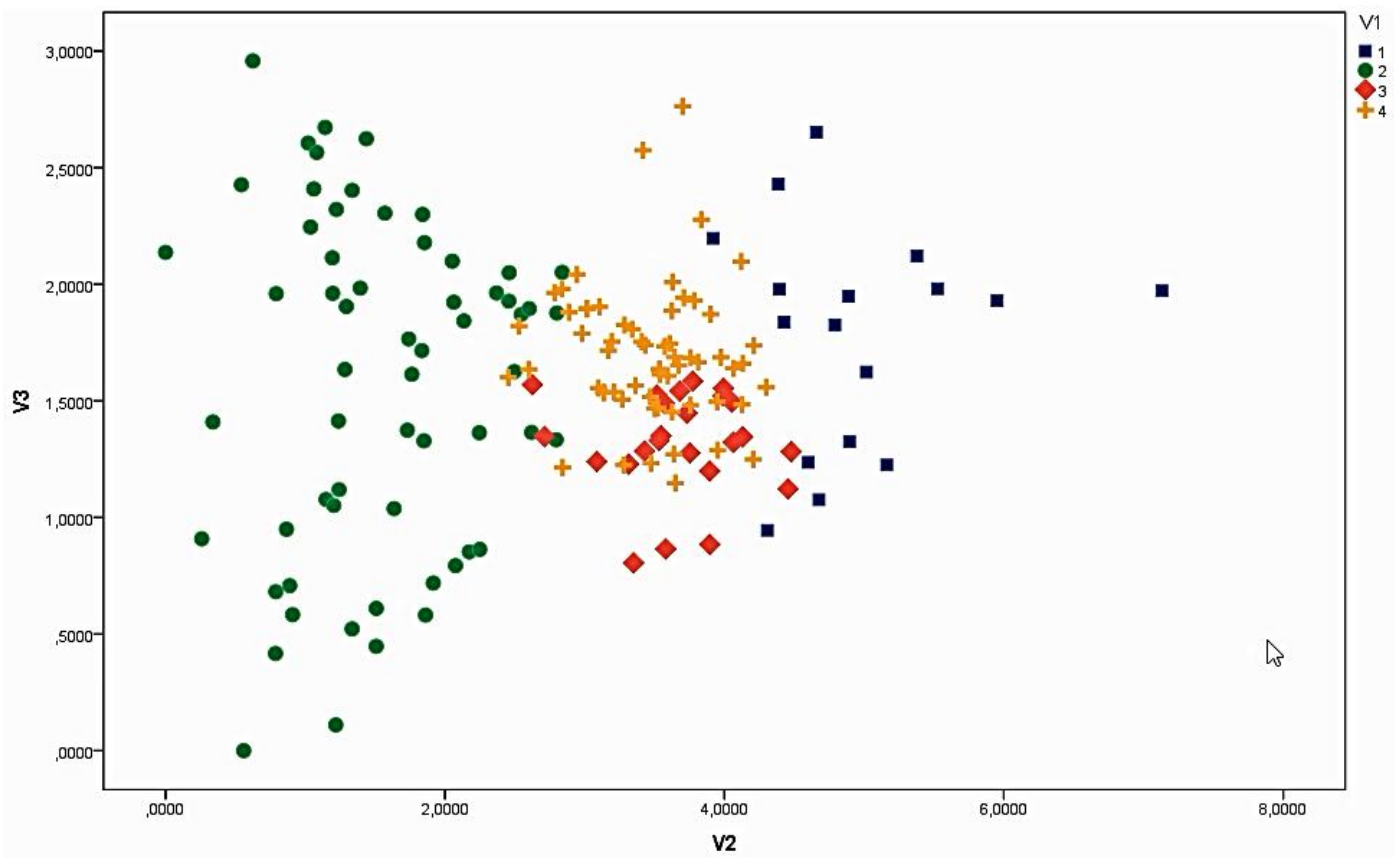

Figure 3. Distribution of steppe communities in Altai Krai along the DCA axis 1 and DCA axis 2. The numbers in the legend correspond to the ordinal numbers of the syntaxons in the prodromus.

Prodromus of higher units of steppe vegetation in Altai Krai

Festuco-Brometea Br.-Bl. et Tx. ex Klika et Hadać 1944 class

Festucetalia valesiacae Br.-BI. et Tx. ex Br.-Bl. 1950 order

Galatellion biflorae Korolyuk 1993 (3) alliance

Festucion valesiacae Klika 1931 (4) alliance

Helictotricho-Stipetalia Toman 1969 order

Helictotricho desertori-Stipion rubentis Toman 1969 alliance

(syn. Plantagini-Calamagrostion epigei Royer 1991) (2)

Stipetalia sibiricae Arbuzova et. Zhitl. Ex Korolyuk et Makunina 2001 (1) order

Steppe communities of Altai Krai belong to the Euro-Siberian Festuco-Brometea class, which includes 3 orders: Festucetalia valesiacae, Helictotricho-Stipetalia, Stipetalia sibiricae. The Festucetalia valesiacae order encompasses mainly steppe meadows and meadow steppes of forest steppe landscapes. The order includes 2 alliances. The Galatellion biflorae alliance is represented mainly by alkaline meadow steppes and steppe meadows. The Festucion valesiacae alliance includes meadow and bunchgrass steppes. The Helictotricho-Stipetalia order represents true steppes, to a lesser extent - meadow steppes. The Helictotricho desertori - Stipion rubentis alliance, referring to this order, is represented by meadow and rich herb-bunchgrass steppes. The Stipetalia sibiricae order refers to the Altai-Sayan mountains and includes rich herb steppes (Makunina et al., 2010; Korolyuk, 2014).

From the environmental perspective, the hierarchy of higher classification units is justified as follows. The performed ordination analysis shows that the leading environmental factors are humidification, salinization, soil structure and anthropogenic factor (grazing). The $\mathrm{X}$ axis is characterized as a humidification gradient and steppe communities represent the following series: the Helictotricho desertori-Stipion rubentis alliance - the Festucion valesiacae alliance — the Galatellion biflorae alliance - 
- the Stipetalia sibiricae order. The $Y$ axis is the gradient of soil structure and the anthropogenic factor (grazing), with which the Helictotricho desertori-Stipion rubentis alliance represents the largest amplitude of variation.

\section{Conclusion}

Thus, modern requirements call for the use of special quantitative studies to establish the ecological and floristic integrity and indicative characters of units and their hierarchical status. Undoubtedly, an effective and reputable approach to the solution of these problems is multidimensional ordination analysis (Detrended correspondence analysis), which is characterized by studying the variability of the plant communities floristic composition and its distribution along the ordination axes. It is the methods of indirect ordination that allow determining and evaluating what environmental parameters explain the observed ordination pattern.

The method described in the work is implemented in various software systems, which allows automating all calculations. This, in its turn, makes it possible to process large amounts of data, which is extremely necessary at the current level of phytocenology development.

The ordination method that was applied in this work showed a high degree of ecological and floristic integrity and informativeness of the steppe vegetation syntaxonomic units of the Broun-Blanquet classification. First of all, as can be seen from the obtained ordination diagram (Figure 3), it is a clear demonstration of the principle of vegetation cover hierarchical organization, developed by V.B. Sochava (1979) (Ermakov et al., 2016), according to which first-order bonds are determined by climate, and second-order bonds are determined by relief features.

\section{References}

Anderson, A.J.B. (1971). Ordination methods in ecology. Journal of Ecology, 59, 713-726.

Cherepanov, S.K. (1995). Sosudistyye rasteniya Rossii i sopredelnykh gosudarstv. Sainct Petersburg.

Goodall, D.W. (1954). Objective methods for the classification of vegetation. III. An essay in the use of factor analysis. Austral. J. Bot., 2, 304-324.

Gower, J.C. (1971). Statistical methods of comparing different multivariate analyses of the same data. Mathematics in the archaeological and historical sciences. Ed. P. Tautu. Edinburgh: Edinburgh University Press, 138-149.

Hill, M.O. (1979). Decorana - a Fortran program for detrended correspondence analysis and reciprocal averaging. N.-Y.

Hill, M.O. (1973). Reciprocal averaging: an eigenvector method of ordination. J. Ecol., 61, 237-249.

Hill, M.O., Gauch, H.G. (1980). Detrended correspondence analysis: an improved ordination technique. Vegetatio, 42, 47-58.

Korolyuk, A.Yu. (2014). Soobshchestva klassa Festuco-Brometea na territorii Zapadno-Sibirskoy ravniny. Rastitelnost Rossii, 25, 4570.

Legendre, P., Anderson, M.J. (1999). Distance-based redundancy analysis: testing multispecies responses in multifactorial ecological experiments. Ecological Monographs, 69, 1-24.

Makunina, N.I., Korolyuk, A.Yu., Maltseva, T.V. (2010). Rastitelnost Biysko-Chumyshskoy vozvyshennosti. Rastitelnost Rossii, 16, 40-55.

Mirkin, B.M., Naumova, L.G. (2012). Sovremennoye sostoyaniye osnovnykh kontseptsiy nauki o rastitelnosti. Ufa: Gilem.

Novakovskiy, A. (2008). Metody ordinatsii v sovremennoy geobotanike. Vestnik Instituta biologii Komi. Ural Branch, Russian Academy of Science, 10, 2-8.

Ordination Methods for Ecologists. Oklahoma State University. Available from: http://ordination.okstate.edu

Ovcharova, N.V., Yamalov, S.M. (2013). Sintaksonomicheskiy i ordinatsionnyy analizy vosstanovitelnykh suktsessiy travyanoy rastitelnosti pravoberezhya reki Obi (Altayskiy kray). Izvestiya Samarskogo nauchnogo tsentra. Russian Academy of Science. Samara.

Polevaya geobotanika. (1964.) Moscow; Leningrad: Academy of Science of the USSR.

Ramensky, L.G. (1930). Zur Methodik der vergleichenden Bearbeitung und Ordnung von Pflanzenlisten und anderen Objecten, die durch mehrere verschiedenartig wirkende Faktoren bestimmt warden. Beitr. Biol. Pflanzen (Breslau), 18(2), $269-304$.

Rao, C.R. (1964). The use and interpretation of principal component analysis in applied research. Sankhya. Ser. A. V., 26, 329-358. Shitikov, V.K., Zinchenko, T.D. (2019). Mnogomernyy statisticheskiy analiz ekologicheskikh soobshchestv (obzor). Teoreticheskaya i prikladnaya ekologiya. 1, 5-11.

Tenenhaus, A., Tenenhaus, M. (2011). Regularized generalized canonical correlation analysis. Psychometrika, 76, $257-284$.

Ter Braak, C.J., Smilauer, P. (2002). CANOCO Reference manual and CanoDraw for Windows User's guide: Software for Canonical Community Ordination (version 4.5). Ithaca: Microcomputer Power.

Ter Braak, C.J.F. (1986). Canonical correspondence analysis: a new eigenvector technique for multivariate direct gradient analysis. Ecology, 67, 1167-1179.

Ter Braak, C.J.F., Smilauer, P. (2012). CANOCO Reference Manual and User's Guide: Software for Ordination (version 5.0). Wageningen: Biometris.

Weber, H.E., Moravec, J., Theurillat, J. (2000). Internetional Code of Phytosociological Nomenclature. J. Veg. Sci.11(5), 739-768. Westhoff, V., van der Maarel, E. (1973).nThe Braun-Blanquet Approach. Handbook of Vegetation Science. P.S. Ordination and classifi cation of communities. The Hague.

Yermakov, N.B., Larionov, A.V., Polyakova, M.A., Plugatar, Yu.V. (2016). Ekologicheskaya interpretatsiya vysshikh yedinits stepnoy rastitelnosti v gorakh yuga Sredney Sibiri metodom kolichestvennoy ordinatsii. Zhurnal obshchey biologii, 77(4), $293-302$.

\section{Citation:}

Ovcharova, N.V., Matsyura, A.V. (2020). Ecological ordination of the grass vegetation in Altai Krai. Ukrainian Journal of Ecology, 10(5), $192-196$. 